\section{Mineral composition of bauxite residue and their surface for innovation materials}

Olga B. KOTOVA - Institute of Geology, FRC Komi SC, UB RAS, Russian Federation • kotova@geo.komisc.ru

ILIA N. RAZMYSLOV - Institute of Geology, FRC Komi SC, UB RAS, Russian Federation • razmyslov-i@mail.ru

JAMAL EldIN F. M. IBRAHIM - Institute of Ceramics and Polymer Engineering, University of Miskolc, Hungary - jamalfadoul@gmail.com

DMITRY A. SHUSHKOV - Institute of Geology, FRC Komi SC, UB RAS,

Russian Federation - dashushkov@geo.komisc.ru

Érkezett: 2020. 06. 30. - Received: 30. 06. 2020. - https://doi.org/10.14382/epitoanyag-jsbcm.2020.22

\section{Abstract}

Natural aluminum ores and aluminosilicate residues are an important component in the development of strategies for the modification of composites, sorbents and other functional materials. The properties of bauxite and bauxite residue were studied by XRD, SEM and standard methods of mineral surface. The phase composition, magnetic, sorption and other properties of bauxite residue before and after exposure to chemical and physical methods to be used in industries are presented.

Keywords: bauxite residue, mineral composition, modification, advanced materials Kulcsszavak: bauxitmaradvány, ásványi összetétel, módosítás, korszerú anyagok
Olga B. KOTOVA

is Head of Laboratory of Technology of Mineral Raw, Institute of Geology Komi SC UB Russian Academy of Sciences. Author and co-author of 10 books, 4 patents and more than 200 scientific articles. President of ICAM-2019. The member of Science Council of Russian Mineralogical Society.

Ilia N. RAZMYSLOV

is Junior Researcher, Laboratory of Comprehensive Assessment and Engineering of Georesources, Institute of Geology, FRC Komi SC, UB RAS. Author and co-author of 6 articles.

Jamal Eldin F. M. IBRAHIM is a lecturer in the University of Bahri, Khartoum, Sudan, he graduated from University of Marmara, Istanbul, Turkey, Institute of Pure and Applied Sciences, Department of Metallurgical and Materials Engineering, for the time being, he is a $\mathrm{PhD}$ student in the University of Miskolc, Institute of Polymer and Ceramics Engineering, under supervision of Prof. L. A. Gömze.

Dmitry A. SHUSHKOV is Researcher of Laboratory of Technology of Mineral Raw, Institute of Geology Komi SC UB Russian Academy of Sciences. Author and coauthor of 2 patents and more than 40 scientific articles. Russian Mineralogical Society.

\section{Introduction}

Alumina is an important raw material for the development of the national economy; however, alumina production can result in great environmental problems. Potentially, bauxites are complex ores for aluminum, titanium, gold and rare elements, which determines the combined processing technologies to extract all useful components and use their technological properties [1-4]. Bauxite residue (red mud) are the main byproduct of alumina production. Annually, up to 40 million tons of bauxite residue are resulted in the world, the bulk of which is still not used. The high alkalinity of such wastes adversely affects water, soil and air. Problems include the flow of alkaline solution and bauxite residue because of damaged pipelines or dams. High cost and large land area are also associated with the construction of dams. Bauxite residueis removed from the alumina plant outside the territory in the form of pulp and stored in a specially equipped site - the so-called mud lake. Dried bauxite sludge can be an effective filler of insulation materials, paints, mastics, tile and roll materials for flooring, etc. [1-8]. A significant part of the researches is devoted to composite materials based on aluminosilicates and technologies for modifying physicochemical properties to meet current and future requirements by request of companies involved in processing of raw materials and production of goods in factories. The study of aluminum and other metals is promoted by their attractiveness for many structural components, where special technological properties are important (increased strength, lower weight, etc.) [9-12]. Bauxite residue is a waste from alumina production, which is characterized by a high content of finely dispersed $\mathrm{Fe}, \mathrm{Al}$, and Ti oxyhydrides [8].

In recent years, protecting people and the environment from harmful effects of industrial pollution has become increasingly important. The use of sorbents wins a special recognition to solve a number of problems. The most widely used sorbents are natural clays characterized by chemical stability, mechanical strength, high ion-exchange selectivity for various compounds, low cost in comparison to synthetic organic ion exchangers and other inorganic materials [13-24]. For example, the papers [15-20] were devoted to composites based on analcimemontmorillonite rocks and aluminosilicate wastes (coal fly ash). An important role of integration of mineralogical and technological features of the material composition for predicting behavior in the technological processes of composite formation and their operational characteristics were emphasized.

Bauxite residue is also studied as sorbent $[8,13,21]$. The specific surface area of bauxite residue is $23-25 \mathrm{~m}^{2} / \mathrm{g}$, the density is $3.3-3.4 \mathrm{~g} / \mathrm{m}^{3}$, and the melting point is $1350-1370$ ${ }^{\circ} \mathrm{C}$. It was determined that the maximum sorption capacity of bauxite residue for strontium is $420 \pm 24 \mathrm{mg}$-Eq/100 g. The high sorption properties of bauxite residue allow using it as a sorbent in the construction of technogenic barriers in places of radioactive waste burial.

The bauxite residuehasmineralogical characteristics (mineral and (or) phase composition), the form of occurrence of the useful component, morphostructural features that determine the strategy and tactics of their secondary use (Fig. 1):

- as raw without processing, for example, to recover valuable metals;

- as initial raw after additional processing to obtain industrial resources.

Even today we witness achievements in solving this problem, for example: storage, production of building materials, new materials to protect the environment, extraction of useful elements, etc. [1-22]. 


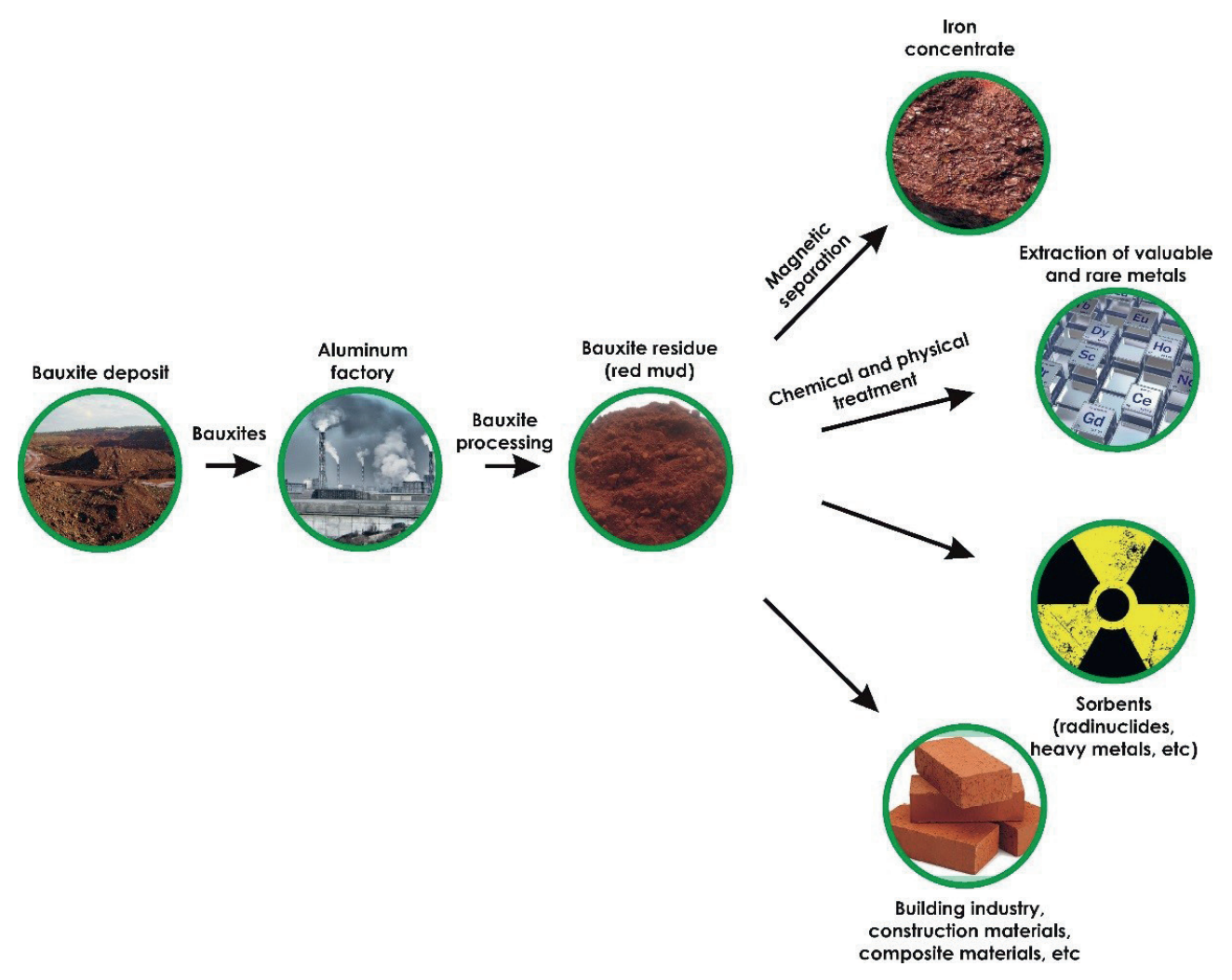

1. ábra A bauxit maradványok hasznositása

Fig. 1 Utilization of bauxite residue

It is very important to study the surface of minerals of bauxite residue (in a fine state), taking into account their structural modification with the aim to process them efficiently. Sorption processes in the system (mineral-environment) were studied earlier. These processes (their mechanisms) are used, for example, to solve technological and environmental problems (for the extraction of non-ferrous metals from the effluents of metallurgical and other industries, the purification of liquid radioactive wastes, etc.) $[10,23]$, as well as in geochemical methods of searches for minerals, including migration and concentration (or dispersal) of various elements and formation of deposits [24].

Our task is to summarize the existing experience, including new data from our researches on bauxite residue, and to demonstrate the potential for practical implementation in various industries, to apply innovative methods for new materials.

\section{Materials and experiments}

\subsection{Materials}

Bauxite residue (red mud) - industrial wastes from the processing of bauxites from the Ural Aluminum Plant.

\subsection{Methods of research}

The chemical composition of the bauxite residue was determined by the silicate analysis. Phase diagnostics was carried out by X-ray diffraction (Shimadzu XRD-6000, CuK radiation). The microelement composition was determined by AES-ICP (ISP-22 Spectrograph). The specific surface area was determined by low temperature nitrogen adsorption method with the help of NOVA 1200e Quantachrome analyzer of surface area and pore size. The density was measured by the pycnometric method. The sorption of radionuclides was carried out according to the procedure described in [21]. Methods for studying the surface of minerals are described in $[23,24]$. The surface study after laser processing was carried out by Raman spectroscopy (Raman scattering) using LabRAM HR800 highresolution Raman spectrometer (Horiba, Jobin Yvon), and optical microscopy was performed with the help of Olympus BX41. The surface was modified by GOR-100M ruby laser with a wavelength $\lambda=694.3 \mathrm{~nm}$ and energy density of about $30 \mathrm{~J} /$ $\mathrm{cm}^{2}$.

\section{Results and discussion}

\subsection{Chemical and mineral composition}

The chemical and mineral composition of bauxite residueis determined by the composition of the initial bauxite and processing methods. The composition varies, but not much. Thus, for example, $\mathrm{Fe}_{2} \mathrm{O}_{3}+\mathrm{FeO}, \mathrm{CaO}, \mathrm{Al}_{2} \mathrm{O}_{3}$ (Table 1) are main components of the chemical composition of the bauxite wastes of the studied samples, the loss on ignition was $12.77 \%$. X-ray analysis was used to diagnose hematite, calcite, lepidocrocite/ goethite, nosean, pyrite, garnets, and X-ray amorphous iron compounds. The specific surface area was $18.7 \mathrm{~m}^{2} / \mathrm{g}$, density 2.84-2.94 $\mathrm{g} / \mathrm{cm}^{3}$. According to AES-ICP data, the bauxite residue contains significant amounts of REE exceeding bulk earth values. The microelement composition is shown in Table 2. 


\begin{tabular}{cccc} 
Component & Content, \% & Component & Content, \% \\
$\mathrm{Fe}_{2} \mathrm{O}_{3}$ & 34.18 & $\mathrm{CO}_{2}$ & 6.00 \\
\hline $\mathrm{FeO}$ & 5.40 & $\mathrm{Na}_{2} \mathrm{O}$ & 2.68 \\
\hline $\mathrm{CaO}$ & 15.27 & $\mathrm{SO}_{3}$ & 2.53 \\
\hline $\mathrm{Al}_{2} \mathrm{O}_{3}$ & 12.17 & $\mathrm{H}_{2} \mathrm{O}$ & 1.96 \\
\hline $\mathrm{SiO}_{2}$ & 7.87 & $\mathrm{Sgen}$ & 1.66 \\
\hline $\mathrm{TiO}_{2}$ & 3.27 & $\mathrm{P}_{2} \mathrm{O}_{5}$ & 0.81 \\
\hline $\mathrm{MgO}^{2}$ & 1.40 & $\mathrm{LOI}$ & 12.77 \\
1. táblázat A bauxit maradvány kémiai összetétele \\
Table 1 Chemical composition of bauxite residue
\end{tabular}

$\begin{array}{lllllllllll}\text { Element } & \mathrm{Sr} & \mathrm{La} & \mathrm{Zr} & \mathrm{V} & \mathrm{Ni} & \mathrm{Ce} & \mathrm{Y} & \mathrm{Cu} & \mathrm{Zn} & \mathrm{Nd}\end{array}$

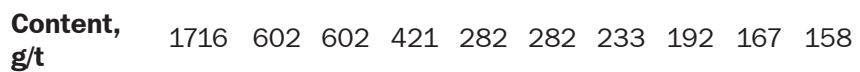

g/t

\begin{tabular}{lcccccccccc}
\hline Element & $\mathrm{Pb}$ & $\mathrm{Ba}$ & $\mathrm{Li}$ & $\mathrm{Co}$ & $\mathrm{Sc}$ & $\mathrm{Nb}$ & $\mathrm{Ta}$ & $\mathrm{Be}$ & $\mathrm{Cd}$ & - \\
\hline $\begin{array}{l}\text { Content, } \\
\mathbf{g} / \mathbf{t}\end{array}$ & 145 & 121 & 104 & 90 & 86 & 27 & 10 & 5 & 2 & -
\end{tabular}

2. táblázat A bauxit maradvány mikroelemeinek összetétele

Table 2 Microelement composition of bauxite residue

\subsection{Granulometric analysis}

The bauxite residue is represented by a fine component, which complicates the extraction of useful minerals by traditional methods, such as magnetic separation. Gravity separation is preferable because it allows improving the content of berthierine in the tails and intermediate product of the concentration table $49-52 \%$, against $43 \%$ related to magnetic separation. This is explained by significant differences in the densities of berthierine and hematite $\left(3.0-3.4 \mathrm{~g} / \mathrm{cm}^{3}\right.$ against $4.9-5.4 \mathrm{~g} / \mathrm{cm}^{3}$ respectively). Hematite is concentrated in fine fractions of bauxite residue, bertierine in larger fractions.

\subsection{Bauxite residue as source of alumina, caustic alkali, iron and rare earths}

From the alumina workshop of the plants, sludge as pulp enters the sludge storages, which pollute the environment and increase the cost of the main products of the plants. With dump bauxite residue, $10-20 \%$ of the alumina, contained in the initial bauxite, and $60-200 \mathrm{~kg}$ of $\mathrm{Na}_{2} \mathrm{O}$ per 1 ton of marketable alumina are irretrievably lost. The annual loss of iron with bauxite residue from a large plant is about 0.5 million tons. Therefore, the bauxite residue should be considered as one of the potential sources of alumina, caustic alkali, iron and rare earth elements.

\subsection{The effect of the condition of surface of bauxite residue minerals on the distribution of magnetic separation enrichment products}

The finely dispersed state of bauxite residue unequivocally indicates a significant influence of the surface condition. Earlier, we studied the finely dispersed mineral-environment system $[23,24]$. The value of the surface charge is important for sorption processes. The value and polarity of the surface charge depends on the position of the Fermi level. Thus, the Fermi level acts as a regulator of the activity of the surface of minerals [23] in sorption processes. When minerals are heated at temperatures $100-150{ }^{\circ} \mathrm{C}$, the hydroxyl coating is broken, and we observe a shift of the point of zero charge of the mineral surface. As a result, we observe a change in the magnetic properties of the samples.

For example, under normal conditions, berthierine and hematite (bauxite residue minerals) possess close magnetic properties and are ineffectively separated by magnetic separation methods. Bertierine significantly reduces the quality of the iron concentrate because of a low content of the latter. For comparison, we carried out magnetic separation of the initial sludge and calcined one for 2 hours at $150{ }^{\circ} \mathrm{C}$. After separation and calcination, the chemical composition of the samples was slightly different from each other (Table 3). Changes occurred in the yield and mineral composition of the calcined samples. The non-magnetic fraction of the calcined sample increased by $22 \%$ compared to the non-calcined sample. The diffraction patterns of the non-calcined samples (non-magnetic and magnetic fractions) are slightly different from each other. The calcined samples showed a changed mineral composition. Two main minerals are diagnosed in the composition of bauxite residue: berthierine (often confused with chamosite, the difference is the absence of $14 \AA$ reflex in berthierine diffraction pattern) and hematite. The intensity of the main peak of berthierine at (7.03 $\AA$ ) in the calcined nonmagnetic sample is much lower than in the non-calcined and, conversely, in the calcined sample, the intensity of the peak of berthierine increases significantly. This gives reason to conclude that even a slight heat treatment $\left(150^{\circ} \mathrm{C}\right)$ (violation of the hydroxyl coating of the mineral) results in a change in the ratio of the yield of minerals in the non-magnetic and nonmagnetic fractions.

\begin{tabular}{|c|c|c|c|c|}
\hline \multicolumn{5}{|c|}{ Chemical composition, wt. \% } \\
\hline \multirow[t]{2}{*}{ Components } & \multicolumn{2}{|c|}{ No calcination } & \multicolumn{2}{|c|}{ Calcination } \\
\hline & Non-magn. & Magn. & Non-magn. & Magn. \\
\hline Mass, \% & 49 & 51 & 71 & 29 \\
\hline $\mathrm{Fe}_{2} \mathrm{O}_{3}$ gen & 4.12 & 5.24 & 4.52 & 5.13 \\
\hline $\mathrm{Al}_{2} \mathrm{O}_{3}$ & 2.41 & 2.21 & 2.21 & 2.29 \\
\hline $\mathrm{SiO}_{2}$ & 6.50 & 6.74 & 7.02 & 7.71 \\
\hline $\mathrm{SO}_{3}$ & 81.48 & 77.97 & 80.89 & 72.56 \\
\hline $\mathrm{TiO}_{2}$ & 0.66 & 1.09 & 0.71 & 1.96 \\
\hline $\mathrm{CaO}$ & 1.22 & 2.24 & 1.33 & 3.99 \\
\hline Mno & 0.44 & 0.73 & 0.34 & 1.39 \\
\hline $\mathbf{P}_{2} \mathbf{O}_{5}$ & 3.11 & 3.72 & 2.92 & 4.86 \\
\hline Sro & 0.06 & 0.08 & 0.06 & 0.12 \\
\hline Total & 100.00 & 100.0 & 100.00 & 100.00 \\
\hline $\begin{aligned} \text { 3. táblázat } & \text { A vizss } \\
& \text { megos } \\
\text { Table } 3 & \text { Distrib }\end{aligned}$ & $\begin{array}{l}\text { ált bauxitmaradv } \\
\text { lása } \\
\text { ution of mass and }\end{array}$ & $\begin{array}{l}\text { sok tömegér } \\
\text { emical com }\end{array}$ & $\begin{array}{l}\text { és kémiai összetét } \\
\text { ition of studied bc }\end{array}$ & $\begin{array}{l}\text { nek } \\
\text { ite residue }\end{array}$ \\
\hline
\end{tabular}

\subsection{Sorption properties of bauxite residue}

Bauxite residue is characterized by a high sorption activity against natural long-lived radionuclides - uranium, radium, 
thorium $\left(\mathrm{U}^{238}, \mathrm{Ra}^{226}, \mathrm{Th}^{223}\right)$. The kinetics of sorption of radionuclides by bauxite residue [21] showed that more than 95 and $97 \%$ of uranium and radium, respectively, are extracted from the solution within 30 minutes of interaction. After 2 hours, more than $98.8 \%$ of radium (the content in the solution is below the detection limit) is sorbed by bauxite residue. The distribution coefficient for radiation was more than $4040 \mathrm{ml} / \mathrm{g}$. With increasing reaction time, uranium recovery increases slightly and reaches a value of $96.63 \%$. Thorium sorption proceeds lower: after $1 \mathrm{~h}$, about $20 \%$ is recovered, after $24 \mathrm{~h}-$ more than $60 \%$. The study of desorption characteristics showed that sorbents had a high absorption strength (or low total desorption). When interacting with water and ammonium acetate, the desorption of radionuclides was less than $1 \%$; during acid treatment, radium and uranium were most strongly retained (desorption was 6.3 and $11.6 \%$, respectively), and radium was the least stable (up to $48.4 \%$ was desorbed into solution). The use of bauxite wastes as sorbents or additional material in various fields of technology does not solve the problem of processing large quantities of this waste product from alumina production. Therefore, in recent years, in many countries of the world, extensive research has been conducted on the recovery of valuable components from bauxite residue. A number of papers suggest to usebauxite residueas raw material for iron, gold, platinum, $\operatorname{REE}[2,4,8,21,25]$.

We studied the content of radioactive elements in bauxite and bauxite residue. For example, the thorium content in bauxite residue is about the same as in bauxite, uranium is 14 times lower, and radium is 10-6 times lower.

\subsection{Modification of structure and properties}

Bauxite residue is used as raw material for Fe production. For the effective development of this industrial product, technological enrichment schemes should provide for a low-waste process: along with obtaining iron-containing commodity concentrates, it is necessary to obtain concentrates of other available minerals, for example, valuable metals.

Bauxite residue, accumulated in tailings, undergo significant transformations during energy impacts in terms of microand nanodispersed oxyhydroxides of iron and REE, which optimizes a number of physical and technical properties of sludgeand expands the potential for practical implementation in various industries, while creating new materials. For example, in $[4,8]$, mechanisms of the conversion of weakly magnetic iron-containing minerals (hematite, goethite) to highly magnetic minerals (magnetite, maghemite) under the influence of external physicochemical factors were considered.

The laser agglomeration technology proposed in [25] is an alternative to cyanidation and amalgamation technologies, which has a negative impact on the environment.

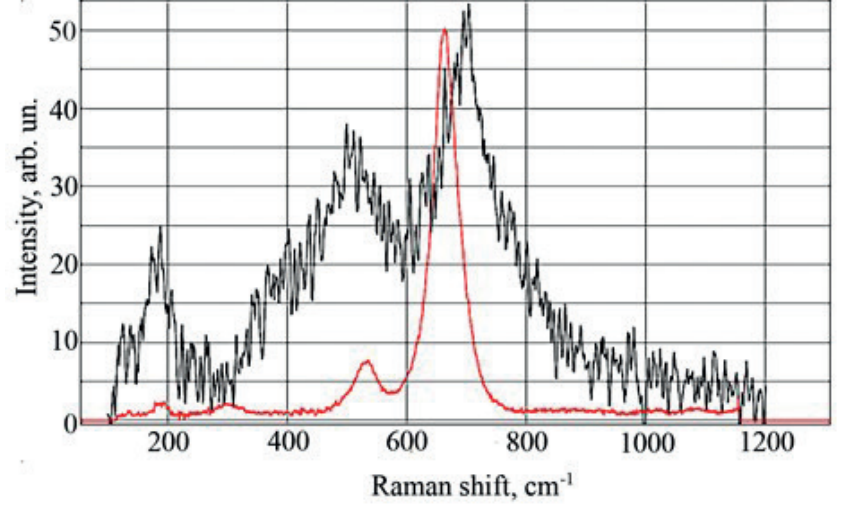

Fig2-1

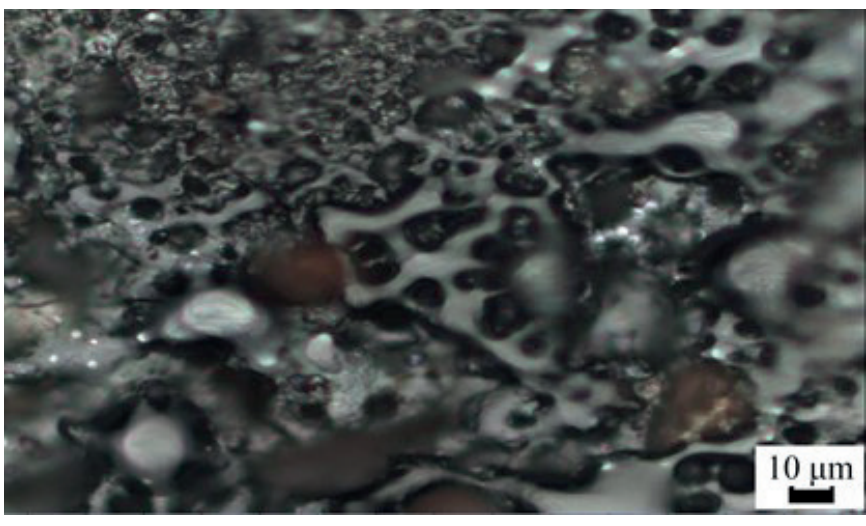

Fig2-2

2. ábra A Raman spektrum és a felület a besugárzási zónában

Fig. 2. Raman spectrum and surface in the irradiation zone

We determined that in the area of laser irradiation, the intensive formation of a new phase is taking place. According to Raman spectroscopy data, the newly formed phase is magnetite (Fig. 2). In this case, it is worth noting the heterogeneity of the magnetite film at the submicron level. The irradiation surface is a magnetite matrix interspersed with silica, hematite, pyrite.

The impact of laser irradiation on finemineral raw materials (bauxite residue) containing hard-to-enrich, colloidal gold and other noble metals, REE and RME results in agglomeration processes with the formation of coarse particles in the form of a drop-like shape with particle sizes one to two orders of magnitude larger than the original ones. As a result of laser melting, the substance is redistributed with the concentration and agglomeration of valuable metals (gold, platinum, hafnium, tungsten, bismuth, etc., the list depends on the experimental conditions), which are "invisible" before processing [25].

\section{Conclusions}

This article is devoted to the prospects of using bauxite residue as a source of metals and advanced materials. An important role of integration of mineralogical and surface features of rad mud for innovative new material were emphasized.Complex forms of occurrence of useful components of bauxite residue and their technological properties were revealed. We emphasized the influence of the surface state of bauxite residue minerals on their physical and chemical properties. It was noted that various physical and chemical influences on bauxite residue 
canresult in a fundamental improvement of their useful properties. The use of bauxite residue as an additional material (in composites, cement, etc.) does not solve the problem of processing large quantities of this dump product of alumina production. Therefore, we suggest using bauxite residue as raw material for metals, REE, etc. The use of bauxite residue as sorbent (radionuclides, heavy metals, etc.) is one of the promising areas of waste utilization.

\section{Acknowledgements}

The authors are thankful to Geonauka Center for Collective Use, where we conducted our studies. The reported study was funded by RFBR and NSFC according to the research project RFBR № 20-55-53019 and NSFC № 4191101331, 41672039. The studies were supported by the program "Main directions of integrated assessment and efficient use of georesources of Timan-Northern Ural-Barents Sea Region" GR AAAA-A19-119031390057-5.

\section{References}

[1] Kotova, O., Vakhrushev, A. (2011): Timan bauxites: Mineralogical and technological features. Vestnik of Institute of Geology of Komi SC of UB of RAS. No. 3, pp. 12-16.

[2] Kotova, O., Gasaleeva, G., Vakhrushev, A. (2015): Minerals of Bauxites and Residues: Problems of Processing and Enrichment (Russia). In: Proceedings of the 11th International Congress for Applied Mineralogy (ICAM). Pp. 241-251.

[3] Kotova, O. B., Shushkov, D. A., Gömze A. L., Kurovics E., Ignatiev, G. V., Sitnikov, P. A., Ryabkov, Y. I., Vaseneva, I. N. (2019): Composite materials based on zeolite-montmorillonite rocks and aluminosilicate wastes. Épitöanyag-JSBCM, Vol. 71, No.4, pp.125-130. https://doi.org/10.14382/epitoanyag-jsbcm.2019.22

[4] Razmyslov, I. N., Kotova, O. B., Silaev, V. I. et. al. (2019): Microphase Heterogenization of High-Iron Bauxite as a Result of Thermal Radiation. J Min Sci. Vol. 55, pp. 811-823. https://doi.org/10.1134/S1062739119056185

[5] Bolden, J. et al. (2013): Utilization of recycled and waste materials in various construction applications. American Journal of Environmental Science Vol. 9(1), pp. 14-24.

[6] Rahman, T., Mohajerani, A., Giustozzi, F. (2020): Recycling of Waste Materials for Asphalt Concrete and Bitumen: A Review. J. Materials. Vol. 13, 1495. https://doi.org/10.3390/ma13071495

[7] Czarnecki, L., VAN Gemert, D. (2017): Innovation in construction materials engineering versus sustainable development. Bulletin of the Polish Academy of Sciences Technical Sciences. Vol. 65, No. 6. https://doi.org/10.1515/bpasts-2017-0083

[8] Kotova, O. B., Razmyslov, I. N. (2018): Problems of processing and enrichment of bauxite, waste disposal. Exploration and protection of mineral resources. No. 10, pp. 51-55.

[9] Kumaravel, S., Alagumurthi, N. (2020): Material removal characteristics of Al-SiO 2 composite in WEDM. Építőanyag-JSBCM. Vol. 72, No. 1, pp. 20-24. p. https://doi.org/10.14382/epitoanyag-jsbcm.2020.4

[10] Gherissi, A., Ali, M. (2020): Superficial hardening improvement of nano and micro composite Al TiC. Építőanyag-JSCM. Vol. 72, No. 1, pp. 25-29. https://doi.org/10.14382/epitoanyag-jsbcm.2020.5

[11] Kurovics, E., Kotova, O. B., Gömze A. L., Shushkov, D. A., Ignatiev, G. V., Sitnikov, P. A., Ryabkov, Y. I., Vaseneva, I. N., Gömze, N. L. (2019): Preparation of particle-reinforced mullite composite ceramic materials using kaolin and IG-017 bio-origin additives. Építőanyag-JSCM. Vol. 71, No. 4, pp. 114-119. https://doi.org/10.14382/epitoanyag-jsbcm.2019.20

[12] Shmakova, A., Kanev, B., Gömze A. L., Kotova O. (2018): Crystal chemical characteristics and physical properties of ferrous minerals as the basis for the formation of functional materials. Applied materials science II. Compilation of selected scientific papers. pp. 17-21. (ISBN 978-615-003118-7)
[13] Amritphale, S., Anshul, A., Chandra, N., Ramakrishnan N. (2007): A novel process for making radiopaque materials using bauxite - Red mud. Journal of the European Ceramic Society. Vol. 27, Iss. 4, pp. 1945-1951, https://doi.org/10.1016/j.jeurceramsoc.2006.05.106

[14] Yang, S., Zhang, Y., Yu, J., Huang, T., Qi, T., Chu, P., Qi, L. (2014): Multifunctional honeycomb ceramic materials produced from bauxite residues. Materials \& Design. Vol. 59, pp. 333-338.

https://doi.org/10.1016/j.matdes.2014.02.061

[15] Kotova, O. B., Harja, M., Cretescu, I., Noli, F., Pelovski, Y., Shushkov, D. A. (2017): Zeolites in technologies of pollution prevention and remediation of aquation systems. Vestnik of Institute of Geology of Komi SC UB RAS. No. 5, pp. 49-53, http://doi.org/10.19110/2221-1381-2017-5-49-53

[16] Forminte (Litu), L., Ciobanu, G., Gómez De Castro, C., Kotova, O., Harja, M. (2018): Comparison between new complex coagulant from fly ash and $\mathrm{Al} / \mathrm{Fe}$ coagulants. 4th International Conference on Chemical Engineering (ICCE 2018) - Innovative materials and processes for a sustainable development. Iasi, Romania, 2018.

[17] Kotova, O., Harja, M., Broekmans, M.A.T.M., Gomez de Castro, C. (2018): New smart materials with application in medicine and environmental protection. Proceedings of the 10th Edition of Euroinvent European exhibition of creativity and innovation. Euroinvent 2018. 10-31 Mai 2018 "George Enescu”, Iasi, Romania. P. 550.

[18] Harja, M., Ciobanu, G., Kotova, O. (2017): Comparative study regarding retention of zinc ions by different ion exchange resins. Proceedings book: International Conference "New trends in environmental and materials engineering" (INVENT-INVEST 2017). UNGHENI, ROMANIAMOLDOVA, 12-15, Noiembrie, 2017. (published in the journal The Annals of "Dunarea de Jos" University of Galati, accredited CNCSIS and indexed in CSA)

[19] Harja, M., Kotova, O., Ciobanu, G., Litu, L. (2017): New adsorbent materials on the base of ash and lime for lead removal. Proceedings book: International Symposium "THE ENVIRONMENT AND THE INDUSTRY”. SIMI 2017, Bucharest, Romania, September, 28-29, 2017. http://doi.org/10.21698/simi.2017.0009

[20] Kotova, O. B., Shushkov, D. A. - Gömze, A. L., Kurovics, E., Ignatiev, G. V., Sitnikov, P. A., Ryabkov, Y. I., Vaseneva, I. N. (2019): Composite materials based on zeolite-montmorillonite rocks and aluminosilicate wastes. Építőanyag-JSBCM. Vol. 71, No. 4, pp. 125-130. https://doi.org/10.14382/epitoanyag-jsbcm.2019.22

[21] Kotova, O. B., Moskalchuk, L. N., Shushkov, D. A., Leontyeva, T. G., Baklay, A. A. (2017): Radionuclide sorbents based on industrial wastes: physical-chemical properties and prospects for use. Vestnik of Institute of Geology of Komi SC of UB of RAS. No. 4, pp. 29-36. http://doi.org/10.19110/2221-1381-2017-4-29-36 (in Russian)

[22] Shushkov, D., Kotova, O., Shuktomova, I. (2013): Removal of radionuclides by analcime-bearing rocks. J. Materials Science and Engineering. Vol. 47, pp. 198-202, http://doi.org/10.1088/1757-899X/47/1/012041

[23] Kotova, O. (2013): Clay Minerals: Adsorbophysical Properties. J. Materials Science and Engineering. pp. 170-176.

[24] Ponaryadov, A., Kotova, O., (2020): Phosphate sorption on leucoxene. Vestnik of Geosciences. No 1, pp. 19-23. http://doi.org/10.19110/geov.2020.1.3

[25] Kotova, O., Leonenko, N. (2016): Physics and chemistry of minerals under laser processing. IOP Conf. Ser.: Mater. Sci. Eng. Vol. 123012016. http://doi.org/10.1088/1757-899X/123/1/012016

\section{Ref.:}

Kotova, Olga B. - Razmyslov, Ilia N. - Ibrahim, Jamal Eldin F. M. Shushkov, Dmitry A.: Mineral composition of bauxite residue and their surface for innovation materials Építőanyag - Journal of Silicate Based and Composite Materials, Vol. 72, No. 4 (2020), 135-139. p. https://doi.org/10.14382/epitoanyag-jsbcm.2020.22 